\title{
A Cross-Cultural Comparison of Conflict Management Styles in Multinational Organisations: Empirical Evidence from Serbia*
}

\author{
Marija Runic Ristic, Nikolina Ljepava, Tahir Masood Qureshi, Asli Cazorla Milla**
}

\begin{abstract}
This study explores the conflict management styles of German and Serbian managers in multinational organisations in Serbia. Contrary to most previous cross-cultural studies on conflict management styles, we have analysed not only the impact of the dimensions of individualism vs. collectivism on conflict management styles, but the effect of power distance dimension also. Moreover, none of the previous studies have analysed the conflict of management styles of managers in Southeast Europe, let alone the influence of intercultural interactions in multinational organisations in that region. Our study is based on the survey of 205 German, and 214 Serbian, managers in German multinationals in Serbia. The findings reveal that German and Serbian managers use different conflict management styles and that the status of the conflict partners and gender affect managers' conflict management styles.
\end{abstract}

Keywords: conflict management, conflict management styles, culture, cultural dimensions, the status of a conflict partner, Southeast Europe

JEL Codes:

\section{Introduction}

Today, market globalisation has led to a more diversified workforce. Almost all over the world, we can find employees from various cultural backgrounds. Having a culturally diversified workforce can have multiple benefits, such as greater ranges of creativity, perspectives, and innovation (Schneider/Barsoux 1997). However, managers need to know how to deal with this.

One of the stumbling blocks around maintaining effective work performance in multinational companies is managing interpersonal conflicts that arise due to

* Received: 3.6 .18 , accepted: $8.11 .19,1$ revision.

** Marija Runic Ristic (corresponding author), Ph.D., Assistant Professor, Faculty of Management, m.runicristic@gmail.com. Main research interests: human resource management, organizational behaviour, organizational psychology, employment relations and leadership. Nikolina Ljepava, Ph.D., Assistant Professor, College of Business Administration, American University in the Emirates, Dubai, UAE. Main research interests: digital transformation, consumer and business psychology, cyberpsychology, marketing communication, and application of educational technologies in teaching and learning.

Tahir Masood Qureshi, Ph.D., Associate Professor, College of Business Administration, American University in the Emirates, Dubai, UAE. Main research interests: organizational behaviour, human resource management, business communications, leadership and management.

Asli Cazorla Milla, Ph.D., Assistant Professor, College of Business Administration, American University in the Emirates, Dubai, UAE. Main research interests: digital marketing, emerging technologies and social media, online consumer behaviour and marketing communications. 
cultural differences. Thus, it is crucial for the success of multinational organisations that management understand employees' cultural differences (Boonsathorn 2007). Kuhn and Pool (2000) discovered in their research that the failure of multinational organisations is most often caused by a lack of cultural understanding. Authors of another study came to a similar conclusion, noting that $50 \%$ of American multinational companies in Asia fail due to cross-cultural misunderstanding (Kim 2001).

Interpersonal conflict with someone from one's own culture takes a lot of energy, let alone conflict with people from different cultures. Interpersonal conflict can be explained as a situation where at least two individuals are in opposition because of different objectives, goals and expectations (Rahim 2002). Culture shapes people's interests and values, which are at the core of every conflict, and by doing so, it tailors one's style of handling conflict (Rable 1994). In a multicultural environment, complex problems and tensions do not often in their own right create conflicts, but conflict can arise from differences in the style of handling these conflicts (that result from different cultural backgrounds) (TingToomey et al. 1991).

In previous studies, the connection between cultural background and conflict handling styles has been discovered (e.g. Trubisky et al. 1991; Bochner/Hesketh 1994; Morris et al. 1998; Brew/Crains 2004; Holt/DeVore 2005; Kaushal/ Kwantes 2006; Prohibit/Simmer 2006; Gunkel et al. 2016; Caputo et al. 2018). For instance, Leung (1988) and Chiu and Kosinski (1994) found that Hong Kong Chinese have different conflict management styles than Americans. Also, Taiwanese students showed more preference for a withdrawing and smoothing style than American students (Trubisky et al. 1991). Kagan et al. (1982) reported that Mexicans preferred avoiding and obliging styles more than Americans, who, on the contrary, preferred more dominating and integrating styles. In the study conducted by Elsayed-Ekhouly and Buda (1996), Arab managers showed more avoiding and integrating conflict management styles and, on the other hand, American managers expressed preferences for obliging, dominating and compromising styles. Punnett and Yu (1991) also identified that the cultural background of Canadian managers influences their preference for conflict management style.

Secondly, from a review of existing literature, we have also identified that most cross-cultural studies of conflict management styles have been conducted in Western Europe, South and North America, and Asia (e.g. Ting-Toomey et al. 1991; Elsayed-Ekhouly/Buda 1996; Morris et al. 1998; Oudenhoven et al. 1998; Kozan/Ergin 1999; Ting-Toomey et al. 2000; Oetzel et al. 2001; He et al. 2002; Brew/Crains 2004; Holt/DeVore 2005; Kaushal/Kwantes 2006; Prohibit/ Summer 2006; Kim et al. 2007; Wang et al. 2007; Boros et al. 20010; Ma et al. 2010; Gunkel et al. 2016, Caputo et al. 2018). However, none of these studies 
has looked at conflict management styles in Southeast European countries or Serbia in particular. Considering the strong presence of Central and Western European companies in Serbia, as well as the recent trend for foreign privatisation of industries, it is crucial to understand the potentially culturally based causes of conflict in these organisations.

\section{Motivation for the study}

Serbia, a developing Southeast European country in the process of economic transition, is one of many countries in the Balkan region that have attracted multinational companies seeking investment opportunities.

Dramatic changes have occurred during the last thirty years in Serbia. These extreme changes had profound consequences for all aspects of life in Serbia. At the beginning of the $1990 \mathrm{~s}$, there was the sudden breakdown of socialist Yugoslavia and socialism as an economic, social and political system (Runic Ristic et al. 2017). Moreover, this resulted in the collapse of the old cultural identity and the slow appearance of a new one (Nikolic et al. 2014). The 1990 s were marked by civil war, hyperinflation, sanctions imposed by the UN and exclusion from international trade, which impoverished the majority of the Serbian population. Due to UN sanctions during the 1990 s, countries from the European Union were unable to legally invest in Serbia. A process of economic transition and post-socialist transformation in Serbia, followed by systematic changes, started after 2000. From 2000 onwards, Serbia began integrating into international flows. Due to the law on foreign investment that came into force in 2001, which equalised the obligations and rights of foreign and domestic investors, Serbia was completely opened up to an influx of foreign direct investment (Radenković 2016). Nowadays, foreign direct investments represent a cornerstone of the Serbian development strategy. When we analyse the origin of major foreign investments, we can conclude that most of them come from European Union countries. Table 1 presents the list of countries that have a major share of investments in the Serbian economy. The origins of foreign direct investment are recorded according to the number of projects taking place in Serbia.

Table 1. Foreign Direct Investment (FDI) Ranking by Number of Projects

\begin{tabular}{|l|c|c|c|c|}
\hline Country & $\begin{array}{c}\text { FDI Ranking } \\
\text { by No. of } \\
\text { Projects }\end{array}$ & $\begin{array}{c}\text { FDI flows Outward } \\
\text { (EUR Million) }\end{array}$ & $\begin{array}{c}\text { FDI stock Outward } \\
\text { (EUR Million) }\end{array}$ & $\begin{array}{c}\text { FDI flows towards } \\
\text { Serbia (EUR Million) }\end{array}$ \\
\hline Italy & $18.0 \%$ & 17752 & 473233 & 203.36 \\
\hline Germany & $13.7 \%$ & 51460 & 1335756 & 186.20 \\
\hline Austria & $11.5 \%$ & 3520 & 200316 & 242.80 \\
\hline Slovenia & $8.5 \%$ & 287 & 6023 & 85.39 \\
\hline US & $5.5 \%$ & 280682 & 6361419 & 15.09 \\
\hline
\end{tabular}




\begin{tabular}{|l|c|c|c|c|}
\hline Country & $\begin{array}{c}\text { FDI Ranking } \\
\text { by No. of } \\
\text { Projects }\end{array}$ & $\begin{array}{c}\text { FDI flows Outward } \\
\text { (EUR Million) }\end{array}$ & $\begin{array}{c}\text { FDI stock Outward } \\
\text { (EUR Million) }\end{array}$ & $\begin{array}{c}\text { FDI flows towards } \\
\text { Serbia (EUR Million) }\end{array}$ \\
\hline France & $5.2 \%$ & 63232 & 1279663 & 76.69 \\
\hline Greece & $4.2 \%$ & 1529 & 19224 & 41.96 \\
\hline
\end{tabular}

Source: Development Agency of Serbia (ed.) (2016): Why Invest in Serbia, Belgrade, retrieved from: http://ras.gov.rs/uploads/2016/06/why-invest-may-16-1.pdf

Most of these countries' investments are mainly directed in two or three industries or several similar industries. For example, Italy invests in the automotive, textile and banking industries, Austria invests in the banking and insurance sector as well as telecommunications, France invests in the banking sector, flooring and food industries, the USA invests in call centres, pharmaceuticals, and architectural services, etc. Only Germany invests in more diverse sectors, such as pharmaceuticals, the banking sector, the automotive industry, tobacco and department stores, electrical equipment, metal works and motors, and generators.

The majority of multinational companies that open branches in Serbia most often place foreign managers in leadership roles these companies. As a result, there is a mixture of representatives of different cultures within multinational companies in Serbia. The presence of foreign companies in Serbia brings a cultural diversity to Serbian companies that was not very common twenty years ago. Therefore, managers in Serbia, besides dealing with the challenges of the transitional economy and turbulent changes, are faced also with a diverse workforce.

For the purpose of this research, we analysed the conflict management styles in German multinational companies situated in Serbia. We decided to explore German multinational companies because the government of Serbia considers Germany to be one of its most important business partners and, as it can be seen in Table 1, it is ranked second place on the list of crucial investors by the number of projects. In 2016, the German-Serbian Chamber of Commerce (AHN Serbia) was established. According to the $13^{\text {th }}$ annual survey conducted by the GermanSerbian Chamber of Commerce in 2018, around 400 German companies currently operate in Serbia with more than 45,000 employees (The German-Serbian Annual Survey).

Generally, this paper aims to explore whether German and Serbian managers have a different style of conflict management in multinational organisations in Serbia.

In particular, this study addresses the following research goals:

- To analyse conflict management styles of German and Serbian employees in multinational organisations situated in Serbia; 
- To examine whether the status of conflict partners relates differently to conflict management styles among Germans and Serbians in multinational organisations;

n To determine whether gender relates differently to conflict handling styles among Serbian and German employees in multinational organisations.

This paper consists of three sections. Firstly, we will analyse the literature on the relevant concepts, such as styles of handling conflict, cultural differences and their impact on the styles of handling conflict. Secondly, we will present the methodology and results. Finally, we will elaborate on the limitations of our results and propose recommendations for further studies.

\section{Theoretical background}

\section{Conflict and styles of conflict management}

Conflict in organisations occurs very often and at various organisational levels. Conflict usually arises because of a mismatch of goals, actions and motivation between at least two parties. Conflict does not always have to be real; sometimes it needs only to be perceived to exist (Taylor/Moghaddam 1994). Moreover, it does not necessarily need to have a negative impact if it is appropriately handled. However, it can lead to a decrease in motivation and job satisfaction, which can result in poor job performance (e.g. Derr 1977; Bergmann/Volkema 1989). Thus, conflict management is one of the most frequently studied areas in human resource management and organisational behaviour. Hogan and Goodson (1990) identified that a significant contributing factor to success in multinational corporations is conflict management. Blake and Mounton (1964) first introduced two dimensions in handling interpersonal conflict, i.e. a concern for personal need and a concern for the need of other people. By combining these two dimensions Blake and Mounton (1964) developed four conflict management styles: problem-solving, forcing, withdrawing and smoothing. Rahim (1983) expanded Blake and Mounton's theory by adding the degree of concern not only for self, but also for others, and in doing so he described five styles of handling conflict. These styles are: integrating, obliging, dominating, avoiding and compromising.

An integrating style expresses concern not only for self but also for others. Therefore, it is a problem-solving style, and it addresses differences constructively. It strives to find a solution that will be acceptable for both parties. It is a win-win style and, thus, we can say that it is the preferred style of handling conflict. This style reduces task and relationship conflicts in an organisation (Friedman et al. 2000).

An obliging style is focused on maintaining a relationship and, thus, it expresses high concern for others and low concern for oneself. It should be used when a 
matter of conflict is more significant to another party or when one party thinks that settling conflict will lead to more fruitful results (Rahim 2002).

A dominating style emphasises a win-lose strategy and, therefore, it is usually accompanied by forceful behaviour and forceful tactics. We refer to this style as "competing" because the needs of the other party are often ignored. According to Rahim (2002), a dominating style is acceptable only when we are under pressure to reach a decision quickly.

An avoiding style expresses inability to satisfy the needs and goals of both parties. Therefore, we can also refer to this style as a withdrawal. This style is loselose, and it can be detrimental to both parties especially in a situation when the issue of the conflict is critical (Rahim 2002).

A compromising style is a neither a winning nor a losing style since both parties give up something to reach a mutually acceptable solution. It is acceptable when both parties have equal power. However, by using this style parties are usually not able to identify real problems.

Although people choose conflict management styles which suit a particular conflict situation (Rahim, 1986), a lot of research has shown that styles of handling conflict do not usually change in different situations and that they are mostly influenced by personality traits and demographic characteristics (e.g. Antonioni 1998; Park/Antonioni 2007; Wood/Bell 2008; Gbadamosi et al. 2014).

Conflict is present in every culture; however, every culture deals with it in its own way and styles of handling conflict are affected by cultural values (Chiu/ Kosinski 1994; Brett 2000). In this study, we are going to analyse the influence of cultural values on the styles of conflict management.

Several authors have presented different cultural concepts and dimensions (e.g. Hofstede 1980; Triandis 1995; Inglehart 1997; Hofstede et al. 2010). Although many studies criticise Hofstede's concepts, his approach is still the most widely used and most popular. Moreover, in most existing studies it has been used to analyse the connection between cultural values and styles of conflict management (e.g. Ting-Toomey et al. 1991; Elsayed-Ekhouly/Buda 1996; Oudenhoven et al. 1998; Kozan/Ergin 1999; Ting-Toomey et al. 2000; Oetzel et al. 2001; Brew/Crains 2004; Kaushal/Kwantes 2006; Prohibit/Summer 2006; Kim et al. 2007; Boros et al. 2010; Ma et al. 2010; Gunkel et al. 2016; Caputo et al. 2018).

\section{Conflict management styles: cross-cultural differences}

Culture is the collective programming of the mind which is different for every group (Hofstede 1980: 25). According to Hofstede (2001), five cultural dimensions exist: individualism vs. collectivism, power distance, masculinity vs. femininity, long-term vs. short-term orientation and uncertainty avoidance. Accord- 
ing to Fiske et al. (1998), crucial cultural dimensions that influence psychological processes are individualism-collectivism and power distance. Therefore, individualism-collectivism and power distance are identified as the most important factors in identifying how people from various cultures resolve conflicts.

Ting-Toomey (1988), in her face negotiation theory, explained the connection between cultural orientations and conflict management styles, i.e. how people from different cultures negotiate and manage conflict. According to this theory, cultural norms influence how people from different cultures see face and how differences in face needs lead to different facework strategies during conflict management. There are three types of face needs - self-face, other-face and mutual-face - and facework represents different communicative strategies that people use to satisfy these needs. According to Ting-Toomey (1988), besides cultural variables, individual and situational variables also influence the preference for facework strategies and conflict management styles.

In this study, we analyse two national cultures, German and Serbian. We measured cultures indirectly by relying on Hofstede (2001) scores. According to Hofstede's classification of national cultures, we revealed the following information about the two cultures: Serbia is classified as a high-power distance (score 86 out of 100 on the scale of power distance) and collectivistic culture (score 25 out of 100 on the scale of individualism) (Hofstede 2002). On the other hand, Germany is characterised by low power distance (score 35 out of 100 on the scale of power distance) and high individualism (score 67 out of 100 on the scale of individualism) (Hofstede 2001).

\section{Development of hypotheses}

\section{Hypothesis 1. Cultural differences and conflict management styles}

Among various differences between collectivistic and individualistic cultures (e.g. processed-focused vs. outcome-focused; relational goal-orientation vs. content goal-orientation; work at polychronic pace vs. work at monochronic pace, etc.), a great deal of attention has been given to conflict management styles (Ting-Toomey 1999).

According to Ting-Toomey (2005), people from individualistic cultures are more worried about individual images and individual goals, and thus they are oriented towards the saving of self-face. On the hand, people from collectivistic cultures, who are more concerned about the group's interests and maintaining harmony are more willing to maintain both self-face and other-face. Therefore, individualistic cultures are characterised by direct conflict styles (e.g. a dominating conflict management style), whereas collectivistic cultures are oriented towards indirect conflict styles (e.g. avoiding and obliging styles). 
A review of previous literature has identified that members of collectivistic cultures opt for integrating, compromising and avoiding styles of handling conflict whereas individualists appear to prefer mostly dominating (forcing) styles (Rahim 1983; Ting-Toomey et al. 1991; Morris et al. 1998; Kozan/Ergin 1999; Holt/DeVore 2005; Wang et al. 2007; Gunkel et al. 2016, Caputo et al. 2018). Moreover, according to the study by Ting-Toomey et al. (1991), an obliging style is preferred by people from collectivist cultures more so than by individualists. One of the studies even showed that people from different nations, who belong to an individualistic cultural dimension, use different styles of handling conflict. Oetzel et al. (2001) compared conflict management styles of Germans and Americans and identified that Germans tend to be more direct and confrontational during a conflict and mostly use a dominating style, whereas an American's initial approach is to try to find a solution that would benefit both parties. Americans will use a dominating style only if they cannot reach an agreement. Two more recent studies (Gunkel 2016; Caputo et al. 2018) revealed that collectivism has a positive relationship to an integrating style, and a negative relationship to a dominating style.

As we have already mentioned, in this study we have analysed whether Serbian managers and German managers in multinational companies in Serbia have different preferences for conflict management styles. German managers come from an individualistic, achievement-oriented culture, whereas Serbian managers belong to a collectivist, relationship-oriented society. Culturally different settings shape a German's and a Serbian's differing attitudes towards business. For Serbian managers, relationships are very often more important than rules. It is not only business interests that are important, but personal, friendly relations are also crucial for conducting successful business in Serbia (Podrug et al. 2014). On the other hand, German managers draw a more distinct dividing line between business and personal relations. Contrary to the transparency of communication in German companies, communication in Serbian companies is usually conducted through informal channels. Therefore, it is crucial to maintain good relationships in Serbian companies and, in order to achieve this, Serbian managers try to avoid conflict as much as possible (Gordy 1999; Jones 2001). On the other hand, German managers see conflict as something that is unavoidable since there are always conflicting interests. However, German managers believe that conflicts can eventually lead to better results (Trompenaars et al. 2007). According to Ting-Toomey et al. (2005), Serbian managers, as members of a collectivistic culture, try to save face both for themselves and others, while German managers are more oriented towards saving self-face. Contrary to the Germans' view of conflicts, Serbians see conflict as a negative phenomenon that can destroy interpersonal relations.

Existing research dealing with conflict management styles has not analysed conflict management styles of German and Serbian managers working in multina- 
tional organisations in Serbia. We therefore decided to explore this topic in our paper. Based on the theoretical background outlined above we propose following hypotheses:

H1 a: In multinational organisations in Serbia, German employees tend to use a more dominating conflict management style than Serbian employees.

H1 b: In multinational organisations in Serbia, Serbian employees prefer to use more integrating, obliging, avoiding and compromising styles compared to German employees.

\section{Hypothesis 2. The status of a conflict partner and conflict management styles}

Ting-Toomey (2005) suggested that the power distance dimension should be analysed separately from an individualistic and collectivist dimension in the context of conflict management styles. Although power distance and individualism-collectivism are correlated (e.g. people from a high power-distance culture are usually collectivistically oriented, while individuals from low power-distance culture are usually individualists [Hofstede 1991]), power distance explains cultural aspects differently to collectivism-individualism. Power distance refers to unequal power distribution, but in the context of conflict management and the face negotiation theory it explains whether people prefer conflict management styles that minimise social hierarchies or not.

People from high power-distance cultures are more submissive and come from authoritarian societies (Hofstede 2001). In high power-distance cultures coercive autocratic power is dominant and resistance to this autocratic power is considered face-threatening (Merkin 2006). Thus, people from high power-distance cultures are more oriented towards cooperative and conforming facework strategies (Kirkbride et al. 1991). According to Ting-Toomey (1998), people from high power-distance cultures do not confront each other and communicate directly because it would result in losing face. More hierarchical organisational structures are in evidence in high power-distance cultures because hierarchy preserves people's face. Employees are afraid of approaching and communicating with their superiors, let alone disagreeing with them (Hofstede 1980). Expressing emotions is considered inappropriate in high power-distance cultures.

In contrast with a wide variety of studies that have tested the connection between individualistic and collectivist dimensions and the style of handling conflict, there are only few studies that have analysed the power distance association with different conflict management styles. The findings of most of these studies are mixed and contradictory. Oudenhoven et al. (1998) discovered that the power distance dimension and an integrating style are positively related. Kim et al. (2007) and Prohibit and Simmers (2006) found that power distance has a positive connection with both avoiding and dominating styles of conflict 
management. Contrary to these findings, He et al. (2002) discovered a positive connection between power distance and obliging and avoiding styles, yet revealed a negative connection with an integrating conflict management style. The results of more recent studies, which compared ten cultural clusters, identified a positive association between power distance and avoiding and dominating styles and a negative relation to integrating, obliging and compromising conflict management styles (Gunkel et al. 2016; Caputo et al. 2018). If we know that high power-distance cultures accept inequality and low power-distance cultures do not, then we would expect that individuals from high power distance cultures are more willing to use the styles of conflict management that would permit them to maintain their power distance, i.e. dominating and avoiding styles. On the other hand, individuals from low power-distance cultures would prefer integrating, obliging and compromising conflict management styles (Gunkel et al. 2016). Therefore, the results of the last two studies (Gunkel et al. 2016; Caputo et al. 2018) are more consistent with Ting-Toomey's facework theory and Hofstede's (2001) definition of a power distance dimension.

When we talk about power distance and conflict management style, we also must consider the different status of the respondents because one can express different behaviour depending on whether one is on a par in terms of power with one's conflict partner, or whether one is higher or lower in the power hierarchy. Status indicates the position one has in a hierarchy and it is very often connected to power (Daniels et al. 1997). People exhibit different behaviour depending on the status of their conflicting partner and culture, i.e. whether they are from high power-distance or low power-distance cultures. In high power-distance cultures people make a clear distinction between higher and lower status, while in low power-distance cultures people do not pay such close attention to the status of the individuals (Hofstede 1991). Power distance and the status of conflict partners directly affect the conflict management style of respondents. Chung and Lee (1988) and Kim et al. (2007) showed that respondents from a high powerdistance culture who are not in the power positions are less dominating and confrontational in conflict situations with their superiors. Furthermore, Prohibit and Simmers (2006) discovered that individuals from high power-distance cultures and in positions of power prefer to use a dominating conflict management style.

For decades, in the majority of Serbian public and private organisations, hierarchical organisational structure and centralised authority have been the norm and they have shaped relationships in a formal manner. Since roles are formalised in Serbian organisations, face-threatening situations are less likely to occur. As in most high power-distance cultures, Serbian employees are expected to comply with their superiors and respect them. Serbian managers strive to maintain their power and status in organisations because it is very difficult to achieve them. Personal relations are very important in Serbian organisations and keeping good connections with top management will help one get promoted and gain 
power and status. Since it is difficult to reach power and status in Serbian organisations and it is not only a matter of qualifications, Serbian managers will do anything to stay in a position of power. Therefore, in conflict with subordinates they will use conflict management styles that will help them not to lose face. On the other hand, German organisations are characterised by flatter organisational structures and the presence of a more participative leadership style, and employees are actively involved in decision-making processes. Subordinates consider their managers to be equal to them and they are encouraged to express their own opinions and ideas freely. Therefore, Germans will use more confrontational conflict management styles in conflict situations with their superiors.

Since the status of a conflict partner can determine the style of handing conflict, and as people from high power-distance cultures react differently to the status of a conflict partner than people from low power-distance cultures, we chose to analyse how Serbian and German managers handle conflict with superiors, subordinates and peers. Therefore, we propose the following second hypothesis:

H2: In multinational organisations in Serbia, there is an interaction effect between the status of a conflict partner and nationality on conflict management styles

\section{Hypothesis 3. Gender and conflict management styles}

In addition to the cultural dimensions, gender differences can also influence one's preference for conflict management style. Existing literature on this subject has shown contradictory findings. One group of studies support typical gender stereotypes where women are less confrontational, more cooperative and prefer to use avoiding, obliging and integrating styles, while men are more competitive and prefer to use dominating conflict management strategies (e.g. Yelsma/Brown 1985; Tannen 1990; Holt/DeVore 2005; Ozkalp et al. 2009; Shadare et al. 2011). The other group of studies arrived at results that contradict gender stereotypes (e.g. Christensen/Heavey 1990; Ohbuchi/Yamamoto 1990; Shute/ Charlton 2006; Cingoz-Ulu/Lalonde 2007). For example, Christensen and Heavey (1990) discovered that men use more avoiding strategies of conflict management and that women are more demanding. Finally, the third group of studies identified either small or no differences between genders in relation to conflict management strategies (e.g. Cupach/Canary 1997; Boonsathorn 2007).

In addition to general differences between males and females, culture can also shape their way of thinking, behaving, feeling and handling conflict. Holt and DeVore (2005) studied, to some extent, the influence of gender and cultural differences on conflict management styles. They discovered that men from individualistic cultures prefer a dominating style compared with men from collectivistic cultures. 
Besides having mixed results on the topic of conflict management styles and gender, most of the prior research has not analysed the situation in organisations and whether conflicts that arise in an organisational context are managed differently by male and female employees. Therefore, in this paper we address this phenomenon and propose the following hypothesis:

H3: There is an interaction effect between gender and nationality on conflict management styles in multinational organisations in Serbia.

\section{Research methodology}

\section{Sample}

We conducted the research in majority-owned and co-owned German multinational companies situated in Vojvodina, the Autonomous Province of Serbia; and in Belgrade, the capital of Serbia. The list of organisations was provided by the German-Serbian Chamber of Commerce (AHN Serbia). Our sample includes 46 companies from different areas of business. Since more Serbians than Germans work in these organisations, to achieve a balance between the two groups of participants, we needed to question German participants in only five out of these 46 companies. The total number of participants was 419. Of these, 214 reported that their native country was Serbia and 205 said that they were from Germany (a more detailed explanation is given in Table 3 and Table 4).

Table 3. Managers' distribution by the industry type

\begin{tabular}{|l|c|c|c|}
\hline \multicolumn{1}{|c|}{ Industry type } & $F$ & $\%$ & Number of companies \\
\hline Pharmaceutical & 96 & 22.9 & 3 \\
\hline Automotive & 90 & 21.5 & 11 \\
\hline Commercial banking & 36 & 8.6 & 4 \\
\hline Retail and wholesale groups & 55 & 13.1 & 4 \\
\hline Electrical equipment & 75 & 17.9 & 11 \\
\hline IT & 67 & 16.0 & 14 \\
\hline
\end{tabular}

Table 4. Managers' demographic characteristics

\begin{tabular}{|l|c|c|c|c|c|c|}
\hline \multirow{2}{*}{ Demographic characteristic } & \multicolumn{2}{c|}{ Serbian } & \multicolumn{2}{c|}{ German } & \multicolumn{2}{c|}{ Total } \\
\cline { 2 - 7 } & $F$ & $\%$ & $F$ & $\%$ & $F$ & $\%$ \\
\hline Gender & 140 & 65.4 & 109 & 53.2 & 249 & 59.4 \\
\hline Male & 74 & 34.6 & 96 & 46.8 & 170 & 40.6 \\
\hline Female & 4 & 1.9 & 0 & 0.0 & 4 & 1.0 \\
\hline Age & 57 & 26.6 & 82 & 40.0 & 139 & 33.2 \\
\hline up to 25 years &
\end{tabular}




\begin{tabular}{|l|c|c|c|c|c|c|}
\hline \multirow{2}{*}{ Demographic characteristic } & \multicolumn{2}{c|}{ Serbian } & \multicolumn{2}{c|}{ German } & \multicolumn{2}{c|}{ Total } \\
\cline { 2 - 8 } & $F$ & $\%$ & $F$ & $\%$ & $F$ & $\%$ \\
\hline 36 to 45 years & 83 & 38.8 & 111 & 54.1 & 194 & 46.3 \\
\hline 46 to 55 years & 67 & 31.3 & 12 & 5.9 & 79 & 18.9 \\
\hline over 56 years & 3 & 1.4 & 0 & 0.0 & 3 & 0.7 \\
\hline Education & 23 & 10,7 & 2 & 1,0 & 25 & 6,0 \\
\hline High Schools & 157 & 73,4 & 138 & 67,3 & 295 & 70,4 \\
\hline Undergraduate degree & 34 & 15,9 & 65 & 31,7 & 99 & 23,6 \\
\hline Graduate degree & & & & & \\
\hline
\end{tabular}

Since conflict management styles can vary according to the status of the conflict partner, we asked the participants who their conflict partners were most often: the participants were asked whether they had conflict most often with their superiors, subordinates or peers. $83.2 \%$ of Serbian managers said that their most frequent conflict partners were their upper-level managers (superiors), $8.4 \%$ of managers said that their most frequent conflict partners were their peers and $8.4 \%$ responded that their conflict partners were usually their subordinates. $50.2 \%$ of German managers said that their most frequent conflict partners were their upper-level managers (superiors), $6.3 \%$ of managers said that their most frequent conflict partners were their peers and $43.4 \%$ responded that their conflict partners were usually their subordinates.

\section{Instrument}

In addition to the demographic characteristics of respondents, the questionnaire also provided information about conflict partners. We measured the status of conflict partners by asking respondents who their conflict partners were most often. However, the main objective of the survey was to discover the preferred conflict management style of German and Serbian employees.

The Rahim Organizational Conflict Inventory-II (ROC-II) (Rahim 1983) was used to measure the five conflict management styles: obliging, integrating, avoiding, compromising and dominating. The instrument consisted of 28 items which are anchored to a five-point Likert scale ranging from 5-strongly agree to 1 -strongly disagree. The questionnaire consisted of seven items for integrating, six items for obliging, six items for avoiding, five items for dominating and four items for a compromising style of conflict management. The authors created the subscale on the bases of participants' responses to the items. A higher score on the subscale indicated that a specific participant had a strong preference for a particular style.

We distributed the questionnaire in English. Although the multinational companies that we analysed were from Germany, communication between the Ser- 
bians and Germans studied is mostly in English. The reason for this is the fact that it is very difficult to find a workforce in Serbia that speaks fluent German. Before starting the survey, we asked the management of the companies being surveyed whether employees from both Germany and Serbia were obliged to know and speak English.

\section{Reliability}

We estimated the reliability of the ROC-II scale with Cronbach's alpha. The alpha coefficients for the ROC-II subscale ranged from 0.762 to 0.790 . The coefficient for each subscale was as follows: obliging 0.762 , dominating 0.764 , integrating 0.776 , compromising 0.787 and avoiding 0.790 . Since the value of the alpha coefficient for the overall scale was between 0.754 and 0.790 , we can say that the instrument was reliable at an acceptable level (DeVellis 2003; Kline 2005). According to DeVellis (2003) Cronbach's alpha reliability scores between 0.6 and 0.8 are considered acceptable.

\section{Results}

We first tested our theoretical model with five factors using Structural Equation Modelling (SEM) (AMOS in SPSS). We performed a SEM analysis based on data from 419 managers in multinational organisations in Serbia. The analysis was performed on 28 items anchored to a five-point Likert scale measuring conflict management styles (Rahim 1983) and three questions identifying national culture, gender and the status of conflict partners. Circles represent latent variables and rectangles represent measure variables (Figure 1). We evaluated the assumptions of multivariate normality and linearity. We chose maximum likelihood parameter estimation over other estimation methods because the data were distributed normally (Kline 2005). The hypothesised model appears to be a good fit to the data $(\chi 2=675.68, \mathrm{Df}=422, \mathrm{CFI}=0.967, \mathrm{GFI}=0.900, \mathrm{RMSEA}=0.039$, TLI $=0.963$ ). We did not conduct post-hoc modifications because of the good fit of the data to the model.

Following confirmation of the theoretical model and scale reliability, the confirmation of hypotheses was undertaken. The data was analysed with a one-way and two-way ANOVA. The dependent variables are the conflict management styles, while the independent variables are national culture, gender and the status of conflict partners. 
Figure 1. Structural Equation Modelling (SEM) model

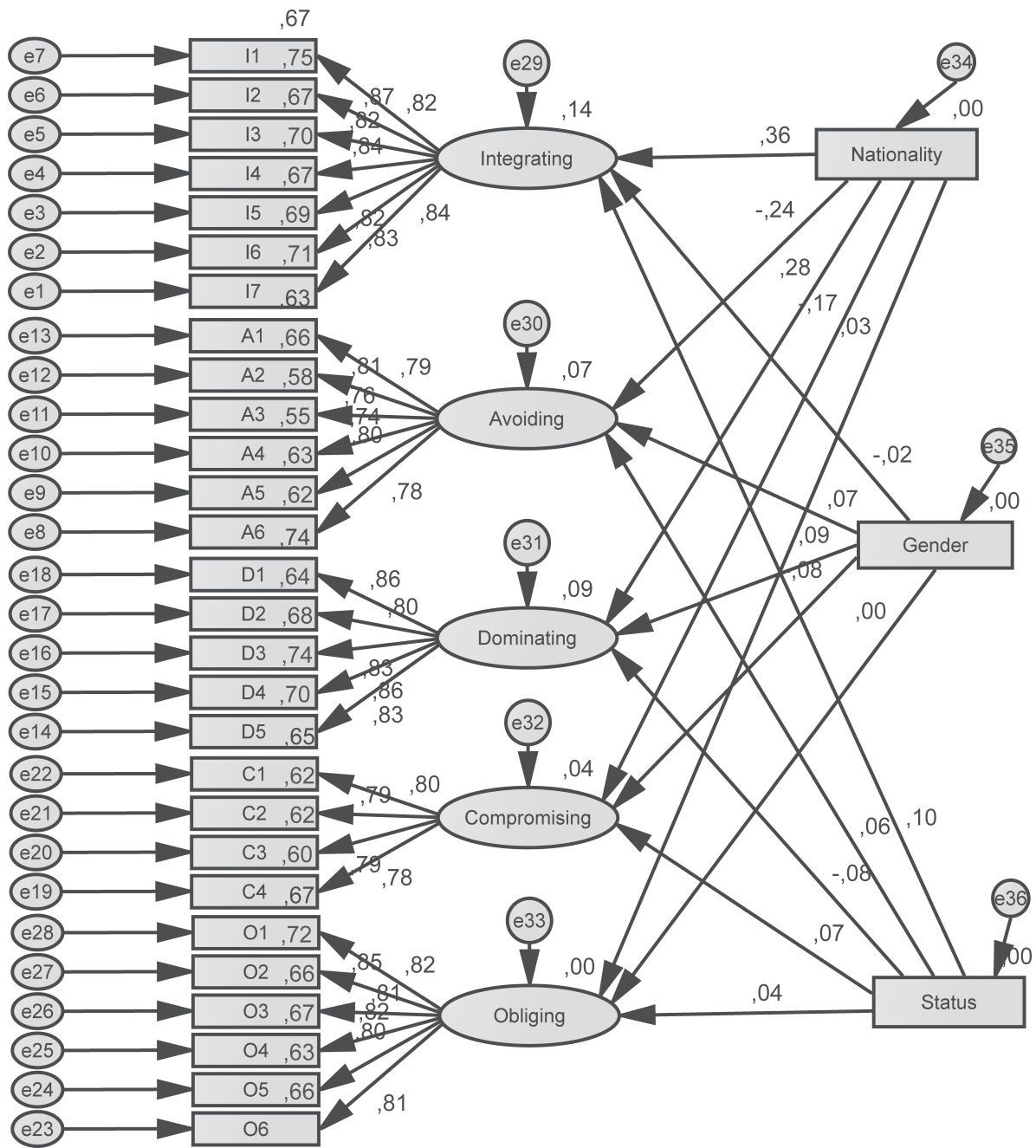

\section{Hypothesis 1 ( $1 a$ and $1 b$ )}

The first hypothesis of this research attempts to determine, in multinational companies, whether Serbians (compared to Germans) would prefer using integrating, avoiding, compromising and obliging styles, while Germans would prefer using a dominating conflict management style. To test the first hypothesis, we used a one-way ANOVA. The preference for each conflict management style is specified as the dependent variable and national culture as the independent variable. 
The results revealed significant differences between two cultures for compromising $(\mathrm{F}=15.567, \mathrm{p}<0.005)$, avoiding $(\mathrm{F}=50.042, \mathrm{p}<0.005)$, dominating $(\mathrm{F}=40.553, \mathrm{p}<0.005)$ and integrating $(\mathrm{F}=49.425, \mathrm{p}<0.005)$, but not for an obliging style of conflict management. Serbians $(\mathrm{M}=3.84)$ resort to a compromising style to a higher degree than Germans $(M=3.43)$. Furthermore, Serbians $(\mathrm{M}=4.42)$ also use more an avoiding style of handling conflict than Germans $(\mathrm{M}=3.76)$. However, Germans $(\mathrm{M}=4.10)$ use more a dominating conflict management style than Serbians $(M=3.34)$ and they $(M=4.30)$ also prefer an integrating style in comparison to Serbian managers $(\mathrm{M}=3.52)$.

The results indicate that both $\mathrm{H} 1 \mathrm{a}$ and $\mathrm{H} 1 \mathrm{~b}$ are partially supported.

\section{Hypothesis 2}

We conducted a two-way ANOVA to analyse the effects of culture and the status of conflict partners on conflict management styles of employees working in multinational organisations. The dependent variable was the preference for each conflict management style and the independent variables were national culture and the status of conflict partners. The ANOVA for this hypothesis reflected as a $2 \times 3$ factorial design (culture $\mathrm{x}$ the status of conflict partner).

The analysis identified that there was a statistically significant interaction between national culture and the status of conflict partner on avoiding $\mathrm{F}$ (2.394) $=7.619, \mathrm{p}=0.001$, partial $\eta 2=0.037$, dominating $\mathrm{F}(2.394)=10.628$, $\mathrm{p}<0.0005$, partial $\eta 2=0.051$ and compromising $\mathrm{F}(2.394)=4.514, \mathrm{p}=0.012$, partial $\eta 2=0.022$ styles of conflict management in multinational organisations. Therefore, we performed an analysis of simple main effects for the status of conflict partner. The statistical significance received a Bonferroni adjustment and it was accepted at the $\mathrm{p}<0.025$ level. All pairwise comparisons were run for each simple main effect. $95 \%$ confidence intervals were reported and p-values were Bonferroni-adjusted with each simple main effect.

There was a statistically significant difference for Serbians in preference for an avoiding style in a conflict situation with their subordinates on one side and their superiors on the other. Serbian managers in conflict with their superiors had a significantly lower mean for an avoiding style than with their subordinates 0.667 ( $95 \% \mathrm{CI}, 0.08$ to 1.25 ), $\mathrm{p}=0.19$. For Serbian managers, an avoiding style is the most preferred style if they have conflict with their subordinates $(M=5.00)$, while for German managers this style is the most used if the conflict partner's status is higher than the individual's status $(M=3.92)$. For both Serbians $(\mathrm{M}=4.75)$ and Germans $(\mathrm{M}=3.62)$, an avoiding style is less preferred in the conflict situations with their peers. Finally, while Serbians $(M=4.33)$ least preferred to use this style in conflict with their superiors, Germans $(\mathrm{M}=3.59)$ used it least in conflict with their subordinates. 
When it comes to preference for a dominating style, a pairwise comparison showed that Serbian respondents in conflict with their superiors had a statistically significant lower mean for a dominating style than in conflict situations with their subordinates (1.58 (95\% CI, 0.86 to 2.31$), \mathrm{p}<0.0005)$. While Serbian managers use a dominating style more in conflict situations with their subordinates $(M=4.75)$ than with their peers $(M=3.75)$ and superiors $(M=3.17)$, German managers use this style in a conflict situation with subordinates $(\mathrm{M}=4.10)$ and superiors $(\mathrm{M}=4.10)$ alike. German managers have a slightly lower preference for a dominating style in conflict with their peers $(M=4.08)$.

Finally, the analysis discovered that Serbian managers use a compromising style mostly in conflict with their superiors $(M=4.50)$ than with their peers $(M=4.25)$ and the least with their subordinates $(M=3.74)$. Serbian managers in conflict with their peers had a statistically significantly lower mean for a compromising style than in conflict with their superiors (0.76 (95\% CI, 0.12 to 1.41$)$, $\mathrm{p}=0.014)$. Regarding a compromising style, the situation with German managers in comparison to the status of conflict partner is slightly different to the one in Serbia. Germans mostly use a compromising style in conflict with their peers. The mean for Germans' preference for a compromising style in conflict with their peers, superiors and subordinates was $\mathrm{M}=3.55, \mathrm{M}=3.54$ and $\mathrm{M}=3.28$, respectively.

Although there was no statistically significant interaction between national culture and the status of conflict partner on an integrating conflict management style, we can see that Germans are more willing to use this style in conflict with their subordinates $(M=4.29)$ than Serbians $(M=3.00)$. Moreover, German managers use an integrating style in the same manner, irrespective of whether they have conflict with their superiors $(\mathrm{M}=4.31)$ or peers $(\mathrm{M}=4.31)$. Serbians mostly use this style in conflict with their peers $(M=4.25)$, then with superiors $(M=3.50)$ and the least with their subordinates $(\mathrm{M}=3.00)$.

Since the results show that there is a significant interaction between national culture and the status of conflict partners on three conflict management styles, we can conclude that $\mathrm{H} 2$ is confirmed.

\section{Hypothesis 3}

We conducted a two-way ANOVA to analyse the interaction effect of gender and national culture on conflict management styles. The dependent variable was the preference for each conflict management style and national culture and gender represented the independent variables. For this hypothesis, the ANOVA reflected as a $2 \times 2$ factorial design (culture $\mathrm{x}$ gender).

The results discovered that there was a statistically significant interaction between national culture and gender on integrating $\mathrm{F}(1.396)=3.942, \mathrm{p}=0.024$, par- 
tial $\eta 2=0.010$, dominating $F(1.396)=5.387, p=0.021$, partial $\eta 2=0.013$ and compromising $\mathrm{F}(1.396)=4.241, \mathrm{p}=0.023$, partial $\mathrm{\eta} 2=0.010$ conflict management styles in multinational organisations in Serbia. We conducted an analysis of simple main effects for gender and statistical significance received a Bonferroni adjustment and was accepted at the $\mathrm{p}<0.025$ level. We ran all pairwise comparisons for each simple main effect. $95 \%$ confidence intervals were reported and p-values Bonferroni-adjusted with each simple main effect.

Although there was not a statistically significant difference in mean for an integrating style for both Serbian and German males and females, it is clear that both German $(\mathrm{M}=4.39)$ and Serbian $(\mathrm{M}=3.71)$ females use a more integrating style than German $(\mathrm{M}=4.22)$ and Serbian $(\mathrm{M}=3.42)$ males.

A pairwise comparison indicated that Serbian males showed a statistically significant preference for a dominating style comparing to Serbian females with mean for a dominating style being 0.52 ( $95 \% \mathrm{CI}, 0.17$ to 0.86$)$ higher for males than for female $(\mathrm{p}=0.004)$. Although there is not a statistically significant difference between German males and females regarding a dominating style, we can say that German males $(\mathrm{M}=4.12)$ use a dominating style a little more than German females $(\mathrm{M}=4.07)$.

The analysis discovered that Serbian males had a statistically significant lower mean for a compromising style than Serbian female 0.42 (95\% CI, 0.12 to $0.72), p=0.007$. The mean for a compromising style for Serbian males and females is 3.70 and 4.12, respectively. On the other hand, a compromising style is used by both male and female German managers $(\mathrm{M}=3.43)$ alike.

As the results revealed that there was a statistically significant effect of the culture and gender on conflict management styles of employees in multinational organisations in Serbia, we can conclude that $\mathrm{H} 3$ is confirmed.

Table 2. Means (M) and standard deviation (SD) for preferences for conflict management styles by culture, conflict partners and gender

\begin{tabular}{|c|c|c|c|c|c|c|c|c|c|c|c|}
\hline & & \multicolumn{2}{|c|}{ Integrating } & \multicolumn{2}{|c|}{ Obliging } & \multicolumn{2}{|c|}{ Avoiding } & \multicolumn{2}{|c|}{ Dominating } & \multicolumn{2}{|c|}{ Compromising } \\
\hline & & M & SD & M & SD & M & SD & M & SD & M & SD \\
\hline \multicolumn{12}{|c|}{ Culture } \\
\hline Serbia & & $3.52^{*}$ & 1.35 & 3.56 & 1.43 & $4.42^{*}$ & 1.02 & $3.34^{*}$ & 1.37 & $3.84^{*}$ & 1.11 \\
\hline $\begin{array}{l}\text { Ger- } \\
\text { many }\end{array}$ & & $4.30^{*}$ & 0.80 & 3.58 & 0.87 & $3.76^{*}$ & 0.85 & $4.10^{*}$ & 0.99 & $3.43^{*}$ & 0.97 \\
\hline \multicolumn{12}{|c|}{ Culture $X$ conflict partners } \\
\hline \multirow{3}{*}{ Serbia } & $\begin{array}{l}\text { Subordi- } \\
\text { nates }\end{array}$ & 3.00 & 1.26 & 3.75 & 1.13 & $5.00^{* *}$ & 0.00 & $4.75^{* *}$ & 0.45 & $3.74^{* *}$ & 0.86 \\
\hline & Superiors & 3.50 & 1.37 & 3.50 & 1.42 & $4.33^{* *}$ & 1.09 & $3.17^{* *}$ & 1.38 & $4.50^{* *}$ & 1.12 \\
\hline & Peers & 4.25 & 0.86 & 4.00 & 1.79 & $4.75^{* *}$ & 0.45 & $3.75^{* *}$ & 0.86 & $4.25^{* *}$ & 0.89 \\
\hline
\end{tabular}




\begin{tabular}{|c|c|c|c|c|c|c|c|c|c|c|c|}
\hline & & \multicolumn{2}{|c|}{ Integrating } & \multicolumn{2}{|c|}{ Obliging } & \multicolumn{2}{|c|}{ Avoiding } & \multicolumn{2}{|c|}{ Dominating } & \multicolumn{2}{|c|}{ Compromising } \\
\hline & & $M$ & SD & $M$ & SD & M & SD & M & SD & $M$ & SD \\
\hline \multirow{3}{*}{$\begin{array}{l}\text { Ger- } \\
\text { many }\end{array}$} & $\begin{array}{l}\text { Subordi- } \\
\text { nates }\end{array}$ & 4.29 & 0.79 & 3.51 & 0.87 & $3.59^{* *}$ & 0.91 & $4.10^{* *}$ & 1.03 & $3.28^{* *}$ & 0.90 \\
\hline & Superiors & 4.31 & 0.83 & 3.64 & 0.82 & $3.92^{* *}$ & 0.69 & $4.10^{* *}$ & 0.94 & $3.54^{* *}$ & 1.02 \\
\hline & Peers & 4.31 & 0.75 & 3.54 & 1.13 & $3.62^{* *}$ & 1.26 & $4.08^{* *}$ & \begin{tabular}{|l|}
1.12 \\
\end{tabular} & $3.55^{* *}$ & 0.97 \\
\hline \multicolumn{12}{|c|}{ Culture X Gender } \\
\hline \multirow{2}{*}{ Serbia } & Male & $3.42^{* *}$ & 1.44 & 3.48 & 1.44 & 4.39 & 1.02 & $3.52^{* *}$ & 1.31 & $3.70^{* *}$ & 1.09 \\
\hline & Female & $3.71^{* *}$ & 1.13 & 3.71 & 1.42 & 4.47 & 1.04 & $3.00^{* *}$ & 1.42 & $4.12^{* *}$ & 1.09 \\
\hline \multirow{2}{*}{$\begin{array}{l}\text { Ger- } \\
\text { many }\end{array}$} & Male & $4.22^{* *}$ & 0.84 & 3.50 & 0.90 & 3.63 & 0.94 & $4.12^{* *}$ & \begin{tabular}{|l|}
1.03 \\
\end{tabular} & $3.43^{* *}$ & 0.97 \\
\hline & Female & $4,39^{* *}$ & 0,75 & 3,65 & 0,82 & 3,89 & 0,71 & $4,07^{* *}$ & 0,95 & $3,43^{* *}$ & 0,97 \\
\hline
\end{tabular}

Notes: ${ }^{*} p<0.005$ one-way ANOVA;

${ }^{* *} p<0.025$ two-way ANOVA

\section{Discussion}

The results of our research confirm some of our expectations, but not all. The results give the support to $\mathrm{H} 2$ and $\mathrm{H} 3$, and $\mathrm{H} 1(\mathrm{H} 1 \mathrm{a}$ and $\mathrm{H} 1 \mathrm{~b})$ is partially supported.

Our study indicates that Serbians prefer avoiding and compromising conflict management styles, while Germans use more integrating and dominating styles. We have not identified a statistically significant difference for an obliging style between German and Serbian managers. Our findings support the assumption that people from collectivistic cultures are less willing to use forcing styles of conflict management than people from individualistic cultures (e.g. Kagan et al. 1982; Leung 1988; Trubisky et al. 1991; Chiu/Kosinski 1994; Elsayed-Ekhouly/ Buda 1996; Holt/DeVore 2005; Boonsathorn 2007; Gunkel et al. 2016). The results support the main feature of collectivistic culture, i.e. the fact that its members tend to foster social harmony and protect social relationships. Our results are also supported by Zabkar \& Makovec Brencic's (2004) research which has shown that Serbians in business relationships are very cooperative, want to get along with others and personal ties are very important to them. Moreover, the recent analyses of the bilateral national stereotypes on the territory of the Western Balkans has revealed that Serbians have a more positive view of themselves than people from other countries in the region have of themselves (Korez/Jurše 2016). The results from this study are also in compliance with the findings from our research which have shown that a compromising style is very dominant among Serbian managers. Both our findings and the findings of the study on the stereotypes have identified that Serbians are very often not able to identify real problems. Contrary to other research we have not concluded that Serbians prefer an integrating style, although they come from a collectivistic culture. Perhaps we have noted these results because the Serbian managers from our sample are 
employed in German multinational organisations, and they are probably reluctant to express their opinion and to seek for the solutions that would be acceptable to them also. Thus, they are more oriented towards withdrawing and compromising styles.

Although our results have shown that Germans use more of a dominating style, we have also discovered that they like to use an integrating style. It is not surprising that Germans prefer a dominating style since people from individualistic countries are more oriented towards direct confrontational styles. However, we did not foresee that they would exhibit a conflict style that is solution oriented.

Since our results have shown that Germans, in addition to a dominating style, like to use an integrating style also, it is, to some extent, contradictory to the findings of the study of Oetzel et al. (2001). Oetzel et al. (2001) compared the conflict management styles of Germans and Americans and discovered that Germans are more direct, assertive and confrontational during conflict and that they are less willing to use an integrating style. We believe that the different results are due to representatives from one culture changing their behaviour and values by being exposed to another culture for a longer period (e.g. Alkhazaraji et al. 1997; Hofstede 2001; Begley 2003; Boonsathorn 2007). Since the German managers from our sample are living in a culture that is dramatically different to their own, i.e. a non-dominating culture, they have become less dominating and confrontational and more willing to use an integrating style of handling conflict.

The other significant finding of our study is that both culture and the status of a conflict partner affect the conflict management styles in multinational organisations. The fact that Serbian managers use avoiding and dominating styles in conflict with their subordinates, while not the case for German managers, is consistent with previous research (Chung/Lee 1988; He et al. 2002; Prohibit/Simmers 2006; Kim et al. 2007; Gunkel et al. 2016; Caputo et al. 2018).

In Serbia, like in most high power distance cultures, it is challenging to gain power and status in an organisation and it is usually more a matter of personal connections than individual qualifications. Thus, once Serbian managers reach a higher position and gain power, they strive to maintain it. Also, Prašnikar et al. (2008) in their research on the culture and values of managers in three transitional countries discovered that Serbian managers value status and consider status to be more important than achievements. Both our research and findings of previous researchers have found that individuals from high power distance cultures who are in a higher position are more oriented towards dominating and avoiding styles.

By using a dominating style, superiors can exert control in conflict with their subordinates. Furthermore, it allows them to stay in power and to maintain the status of inequality and power distance (Rahim 1983). Contrary to Serbian man- 
agers, German managers use a dominating style in conflict with their subordinates and supervisors alike which is typical for a low power distance culture.

Regarding an integrating style, Germans use this more than Serbians when in conflict with their subordinates. This style relies on using cooperative actions and reaching conflict solution and, thus, it is less suitable for maintaining power distance and more acceptable for low power-distance cultures.

Our study has also discovered that people in a higher position in high powerdistance cultures prefer an avoiding style when in conflict with their subordinates. If they withdraw from the conflict, they can maintain a power position while a conflict solution might lead to a changing of the current power and status of conflict partners and result in the redistribution of power (Gunkel et al. 2016).

In high power-distance cultures, hierarchy plays an essential role in both everyday life and organisations. According to Hofstede (2011) subordinates are expected to embrace the interests and view of their superiors. Individuals from high power distance cultures who are not in a higher position behave less confrontationally and competitively (Chung/Lee 1989). Since Serbia is a high power-distance culture, it is logical that a compromising style is mostly used when a conflict partner has a higher-level status. On one hand, a compromising style can enhance harmony and foster good working relations, but on the other hand, it can decrease the level of creativity and innovation in organisations.

Finally, the results of our study have indicated that national culture and gender have an impact on conflict management styles in multinational organisations. So far, the findings regarding the connection between gender and conflict management styles have been inconsistent. Some studies support gender stereotypes where men use more competitive styles while women prefer more harmony-oriented styles (e.g. Tannen 1990; Holt/Devore 2005; Ozkalp et al. 2009; Shadare et al. 2011). The other studies are either in contradiction to gender stereotypes (e.g. Christensen/Heavey 1990; Ohbuchi/Yamamoto 1990; Cingoz-Ulu/Lalonde 2007) or show no significant difference between gender and preference for a particular conflict management style (e.g. Cupach/Canary 1997, Boonsathorn 2007).

The male respondents from our sample rely mostly on a dominating style and females rely more on integrating, regardless whether they are Germans or Serbians. Moreover, Serbian females show a higher preference for a compromising style compared with Serbian males. Therefore, we can conclude that the findings from our study are mostly consistent with the studies that support gender stereotypes. 


\section{Limitations of the study}

There are several limitations of our study. The first one concerns the instruments that we used. The questionnaire was in English because both the Germans and Serbians studied were expected to have a good command of English since they communicate among themselves in English. However, some English words and concepts might have different interpretations that do not apply to Serbian and German cultural contexts. Therefore, someone who is less proficient in English can experience issues in fully comprehending a questionnaire. For future research, we would recommend that instruments be translated into the native language of the respondents while ensuring that the translated version is equivalent to the original one.

The second limitation also refers to the instruments. In our paper, we explain the cultural differences between Germans and Serbians by applying a comparative approach. We indirectly measured culture as nationality and, by doing so, we neglected individual differences within cultures. Even one of the criticisms of Hofstede's concepts emphasises the fact that cultures cannot be considered as homogenous, i.e. there are individual differences among members of one culture (e.g. Kirkman et al. 2006; Gunkel et al. 2016). Therefore, cultural orientation should have been measured directly at the individual level and, thus, we would have been able to see individual differences within the cultural value dimensions.

The third limitation concerns the number of respondents in our research. We believe that it was not large enough to generalise the findings adequately. For future research, we would recommend that it should include more German and other multinational organisations from different sectors. Moreover, it would be useful for further research to compare conflict management styles in multinational organisations in other Western Balkan countries.

The fourth limitation refers to the sample. Our research was conducted in the multinational companies situated in Vojvodina and Belgrade. The Vojvodina region and the capital of Serbia, Belgrade, are very different from the rest of Serbia, as they represent the richest and most developed parts of Serbia. Vojvodina is the agricultural heart of Serbia and is rich with petroleum and natural gas. Therefore, most foreign investments are made in this region. Gordy (1999) describes the difference between Vojvodina and Belgrade on one side and the rest of the Serbia on another as epitomising the conflict between modern urban values and traditional rural values. The history of Vojvodina differs from the rest of Serbia. For centuries it was part of the Austro-Hungarian Empire and in 1918 it became the part of the Kingdom of Serbs, Croats and Slovenes, later renamed Yugoslavia. Vojvodina is an ethnically highly diverse region, where Serbians represent around $65 \%$ of the population and Hungarians, Croats, Slovaks and Romanians the rest. We can say that Vojvodina represents the most diverse re- 
gion in Serbia. Therefore, it is easier for the population in Vojvodina to adapt to multinational companies that consist of a diverse workforce. Perhaps the results would have been different if we had conducted the research in other parts of Serbia. We propose that further research should be conducted also in multinational companies situated in other regions in Serbia.

Finally, the number of years Germans have spent in Serbia should have been included as a significant variable in our study. Prior studies have asserted that cultural adaptation can be influenced by the time one spends in a culture, i.e. people can change their behaviour to adjust to a new culture (e.g. Alkhazaraji et al. 1997; Hofstede 2001; Begley 2003; Boonsathorn 2007). We suggest that the issue of cultural adaptation should be included in the future analysis of conflict management styles in multinational organisations.

\section{Implications}

\section{Theoretical implications}

Despite the continuous analysis of the influence of culture on the styles of conflict management in the current literature, several important issues still need to be addressed. In our study, we have tried to address some of these issues.

Firstly, as we have already mentioned, most previous research has analysed the connection on a single cultural dimension, mainly individualism and collectivism, and conflict handling styles. Moreover, previous research on conflict management styles has not been conducted in Southeast Europe. Our paper addresses this research gap by analysing conflict management styles of Germans and Serbians in multinational organisations in Serbia. To the best of our knowledge, this is the first example of research that examines the influence of an individualistic, low power-distance culture and a collectivist, high power-distance culture on conflict management styles in multinational organisations in Southeast Europe.

Although Gunkel et al. (2016) conducted extensive research on the relationship between all cultural dimensions (including the power distance dimension) and styles of handling conflict in 16 countries, none of the countries of the Western Balkan region, particularly Serbia, was included in that study. The only Southeast European country that was included in the study was Romania. However, the study analysed the impact of emotional intelligence and cultural values on conflict management styles.

Secondly, in our study we have shown that the power distance dimension and the status in organisational hierarchy of conflict partners directly affect respondents' conflict management style, and in conflict situations respondents exhibit different behaviour depending on whether they are on power or under power, a novel finding in the research. 
Thirdly, contrary to most cross-cultural studies which analyse the interaction of people from the same culture and compare several cultures, our study examined the intercultural interactions which could influence the participants' conflict management styles. The findings show that Germans might feel willing to use less competitive styles of handling conflicts when dealing with Serbians who are oriented towards in-group goals and concerned about maintaining harmonious relationships and social harmony and protecting interpersonal connections.

\section{Managerial implications}

This paper provides implications for the business community and international human resources practices on several issues.

German managers who work in Serbia need to be aware of the different approach to business and different work ethics and discipline in Serbian organisations, since these factors can all be sources of conflict. The work discipline among Serbian managers can sometimes be very low. They do not usually meet deadlines, can cover up mistakes and oversights and can sometimes be very unprofessional. From a German perspective such work ethics and discipline are not acceptable (Trompenaars et al. 2007). Serbian managers maintain business relationships through friendships, informal gatherings, and wining and dining, etc. German managers are more accustomed to legally based business relationships. Since Serbians belong to a collectivist, relationship-oriented culture, they do not understand German straightforwardness (Schroll-Machl 2013). They expect criticism to be expressed indirectly and to be accompanied with encouraging words. Moreover, Serbian managers use more informal channels of communication, while Germans are more oriented towards transparent communication. Our results have shown that Serbian managers prefer using a compromising style in conflict situations with their superiors. On the other hand, German managers expect that their counterparts express open disagreement and they do not consider it to be the end of cooperation. Germans believe that conflicts mainly lead to positive and innovative results (Schroll-Machl 2013). On the other hand, Serbian managers see conflict as something that should be avoided because it can lead to broken relationships.

For decades, in most Serbian organisations a hierarchical organisational structure and centralised authority have been present and they have shaped relationships in organisations. In such organisational environments it has been expected that Serbian managers will use a compromising style when in conflict with their superiors and a dominating and avoiding style when in conflict with their subordinates. The entrance of multinational organisations into the Serbian market has introduced other forms of organisational structure. However, our results have shown that Serbian managers are still more comfortable using strategies of handling conflicts that are predominantly present in hierarchically structured organi- 
sations. If Serbian managers are not able to accept and adjust to other forms of organisational structures it will hinder the progress of multinational organisations in Serbia.

German managers need to be informed about different business practices when coming to work in Serbia since they can be stumbling blocks when attempting to work with Serbian counterparts. They need to be trained on the cultural differences that they will be face once they arrive in Serbia. In that way, they will be not only more aware of cultural issues but also adapt more easily to Serbian culture. Not only do German managers need to be prepared and trained for work in Serbia, but Serbian managers who work in multinational companies also need to receive training. Serbian managers should be taught to be more assertive, to handle conflict in more integrating ways and should be trained to work in culturally diverse environments. Both German and Serbian managers should learn how to interact in conflict situations in intercultural contexts.

Nowadays, as we mentioned earlier, it is very attractive for Western companies to open branches in Serbia. According to Hofstede's cultural dimensions, German cultural dimensions are similar to the cultural dimensions of other countries that operate in Serbia (e.g. Western European countries and America have similar cultural dimensions to those of Germany). Therefore, the inputs from our study can have significant implications for management - especially human resource departments - of companies that are active in Southeast Europe, particularly in the Western Balkan region.

\section{References}

Alkhazaraji, K.M./Gardner, W.L. III/Martin, J.S./Paolillo, G.P. (1997): The acculturation of immigrants to US organizations: the case of Muslim employees, in: Management Communication Quarterly, 11, 217-65.

Antonioni, D. (1998): Relationship between the big five personality factors and conflict management styles, in: International Journal of Conflict Management, 9, 4, 336-355.

Begley, P.A. (2003): Sojourner adaptation, in: Samovar, L.A./Porter, R.E. (ed), Intercultural Communication: A Reader, Belmont: Wadsworth, 406-12.

Bergmann, T. J./Volkema, R. J. (1989): Understanding and managing interpersonal conflict at work: its issues, interactive processes, and consequences, in: Rahim, M.A. (ed.): Managing conflict: an interdisciplinary approach, New York: Praege, 7-19.

Blake, P.R./Mouton, J.S. (1964): The Managerial Grid. Houston, TX: Gulf publishing.

Bochner, S./Hesketh, B. (1994): Power distance, individualism/collectivism, and job related attitudes in culturally diverse work group, in: Journal of Cross-Cultural Psychology, 25, 233-257.

Boonsathorn, W. (2007): Understanding conflict management styles of Thais and Americans in multinational corporations in Thailand, in: International Journal of Conflict Management, 18, 3, 196-221. 
Boros, S./Meslec, N/ Curseu, P.L./Emons, W. (2010): Struggles for cooperation: conflict resolution strategies in multicultural groups, in: Journal of Managerial Psychology, 25,5, 539554.

Brett, J. M. (2000): Culture and negotiation, in: International Journal of Psychology, 35, 2, 97-104.

Brew, F. P./Cairns, R. (2004): Styles of managing interpersonal workplace conflict in relation to status and face concern: A study with Anglos and Chinese, in: International Journal of Conflict Management, 15, 1, 27-56.

Caputo, A./Ayako, O.B./Amoo, N. (2018): The moderating role of cultural intelligence in the relationship between cultural orientations and conflict management styles, in: Journal of Business Research, 89, 10-20.

Chiu, R.K./Kosinski, F. A. (1994): Is Chinese conflict handling behavior influenced by Chinese values?, in: Social Behavior and Personality, 22, 1, 81-90.

Christensen, A./Heavey, C.L. (1990): Gender and social structure in the demand/withdraw pattern of marital conflict, in: Journal of Personality and Social Psychology, 59, 73-81.

Chung, K.H./Lee, H.C. (1988): National differences in managerial practices, in: Chung, K.H./ Lee, H.C. (ed.): Korean Managerial Dynamics, New York: Praeger, 163-80.

Cingoz-Ulu, B./Lalonde, R.N. (2007): The role of culture and relational context in interpersonal conflict: do Turks and Canadians use different conflict management strategies?, in: International Journal of Intercultural Relations, 31, 443-58.

Cupach, W. R./Canary, D.J. (1997): Competence in Interpersonal Conflict. New York: McGraw-Hill.

Daniels, T. D./Spiker, B. K./Papa, M. J. (1997): Perspectives on organizational communication. Boston: McGraw-Hill.

Derr, C.B. (1977): Managing organizational conflict, in: California Management Review,21, 2, 76-83.

DeVellis, R. F. (2003): Scale development: Theory and applications, Thousand Oaks, CA: Sage.

Development Agency of Serbia (ed.) (2016): Why invest in Serbia, Belgrade, retrieved from: http://ras.gov.rs/uploads/2016/06/why-invest-may-16-1.pdf

Elsayed-Ekhouly, S.M./Buda, R. (1996): Organizational conflict: a comparative analysis of conflict across cultures, in: International Journal of Conflict Management, 7, 1, 71-81.

Europe.

Fiske, A. P./Markus, H. R./Kitayama, S./Nisbett, R. E. (1998): The cultural matrix of social psychology, in Gilber, D./ Fiske, S/Lindsey, G. (ed.), The handbook of social psychology (4th ed.), Boston: McGraw-Hill, 915-981.

Friedman, R.A./Tidd, S.T./Currall, S.C./Tsai, C.J. (2000): What goes around comes around: the impact of personal conflict style on work conflict and stress, in: International Journal of Conflict Management, 11, 1, 32-55.

Gbadamosi, O./Baghestan, A.G./Al-Mabrouk, K. (2014): Gender, age and nationality: assessing their impact on conflict resolution styles, in: Journal of Management Development, $33,3,245-257$.

Gordy, E.D. (1999). The Culture of Power in Serbia: Nationalism and the Destruction of Alternatives. University Park: The Pennsylvania State University Press. 
Gunkel, M/Schlaegel, C./Taras, V. (2016): Cultural values, emotional intelligence, and conflict handling styles: A global study, in: Journal of World Business, 51,4, 568-585.

He, Z./Zhu, J./Peng, S. (2002): Cultural values and conflict resolution in enterprises in diverse cultural settings in China, in: Chen, G.M./Ma, R. (ed.): Chinese conflict management and resolution, Westport: Albex, 129-147.

Hofstede, G. (1980): Culture's consequences. Beverly Hills: Sage.

Hofstede, G. (1991): Cultures and organizations: Software of the mind. London: McGrawHill.

Hofstede, G. (2001): Culture's recent consequences: Using dimensions scores in theory and research, in: International Journal of cross cultural management, 1,1, 11-17.

Hofstede, G. (2002): Images of Europe: Past, Present and Future in: Warner M./Joynt P. (ed.): Managing Across Cultures, Padstow: Thompson.

Hofstede, G./Hofstede, G. J./Minkov, M. (2010): Cultures and organizations. New York City: McGraw-Hill.

Hogan, G.W./Goodson, J.R. (1990): The key to expatriate success, in: Training and Development Journal, 44,1, 50-52.

Holt, J.L./DeVore, C.J. (2005): Culture, gender, organizational role, and styles of conflict resolution: A meta-analysis, in: International Journal of Intercultural Relations, 29,2, 165-196.

Inglehart, R.F. (1997): Modernization and postmodernization: cultural, economic, and political change in 43 societies. Princeton: Princeton University Press.

Jones, C. (2001): A devastated economy, in The Banker, 151(April), 64.

Kagan, S./Knight, G./Martinez-Romero, S. (1982): Culture and the development of conflict resolution style, in: Journal of Cross-Cultural Psychology, 13, 43-59.

Kaushal, R./Kwantes, C.T. (2006): The role of culture and personality in choice of conflict management strategy, in: International Journal of Intercultural Relations, 30, 5, 579-603.

Kim, Y.Y. (2001): Becoming intercultural: an integrated theory of communication and crosscultural adaptation, in: Samovar, L.A./Porter, R.E. (ed.): Intercultural Communication: A Reader, Belmont: Wadsworth, 3-43.

Kim. T.Y./Wang, C.,/Kondo, M./Kim, T. H. (2007): Conflict management styles: the differences among the Chinese, Japanese, and Koreans, in: International Journal of Conflict Management, 18, 1, 23-41.

Kirkbride, P. S./Tang, S. F./Westwood, R. I. (1991): Chinese conflict preferences and negotiating behaviour: Cultural and psychological influences, in: Organization Studies, 12, 365 386.

Kirkman, B. L./Lowe, K.B./Gibson, C.B. (2006): A quarter century of culture's consequences: a review of empirical research incorporating Hofstede's cultural values framework, in: Journal of International Business Studies, 37, 3, 285-320.

Kline, R. B. (2005): Principles and practice of structural equation modelling. New York: Guildford.

Korez Vide, R./Jurše, M. (2016): The Role of Stereotyping in a Culturally Diverse International Business Environment, in: Teorija in Praksa, 53(5).

Kozan, M.K./Ergin, C. (1999): The influence of intra-cultural value differences on conflict management practices, in: International Journal of Conflict Management, 10, 3, 249-67. 
Kuhn, T./Poole, M.S. (2000); Do conflict management styles affect group decision making? Evidence from a longitudinal field study, in: Human Communication Research, 26, 558-90.

Leung, K. (1988): Some determinants of conflict avoidance, in: Journal of Cross Cultural Psychology, 19, 125-36.

Ma, Z./Erkus, A./Tabak, A. (2010): Explore the impact of collectivism on conflict management styles: a Turkish study, in: International Journal of Conflict Management, 21, 2, 169 185.

Merkin, R. S. (2006): Power distance and facework strategies, in: Journal of Intercultural Communication Research, 35, 2, 139-160.

Morris, M.W./Williams, K.Y./Leung, K./Larrick, R. (1998): Conflict management style: accounting for cross-national differences, in: Journal of International Business Studies, 29,4, 719-29.

Nikolic, M./Vukonjanski, J./Nedeljkovic, M./Hadzic, O./Terek, E. (2014): The relationships between communication satisfaction, emotional intelligence and the GLOBE organizational culture dimensions of middle managers in Serbian organizations, in: Journal for East European Management Studies, 19, 4, 387-412.

Oetzel, J./Ting-Toomey, S./Masumoto, T./Yokochi, Y./Pan, X./Takai, J./Wilcox, R. (2001): Face and facework in conflict: A cross-cultural compression of China, Germany, Japan and the United States, in: Communication Monographs, 68,3, 235-258.

Ohbuchi, K./Yamamoto, I. (1990): The power strategies of Japanese children in interpersonal conflict: effects of age, gender and targe, in: Journal of Genetic Psychology, 151, 349-60.

Oudenhoven, J.P./Mechelse, L./Dreu, C.K. (1998): Managerial conflict management in five Europeans countries: the importance of power distance, uncertainty avoidance, and masculinity, in: Applied Psychology, 47, 3, 439-455.

Ozkalp, E./Sungur, Z./Ayse Ozdemir, A. (2009): Conflict management styles of Turkish managers, in: Journal of European Industrial Training, 33, 5, 419-438.

Park, H./Antonioni, D. (2007): Personality, reciprocity, and strength of conflict resolution strategy, in: Journal of Research in Personality, 41,1, 110-125.

Podrug, N./Filipović, D./Stančić, I. (2014): Analysis of cultural differences between Croatia, Brazil, Germany and Serbia, in: Economic Research-Ekonomska istraživanja, 27,1, 818829.

Prašnikar, J./Pahor, M./Vidmar Svetlik, J. (2008): Are national cultures still important in international business? Russia, Serbia and Slovenia in comparison, in: Management: Journal of Contemporary Management Issues, 13, 2, 1-26.

Prohibit, Y. S./Simmers, C.A. (2006): Power distance and uncertainty avoidance: a cross-national examination of their impact on conflict management modes, in: Journal of International Business Research, 5,1, 1-19.

Punnett, B. J./Yu, P. (1991): Attitudes towards doing business with the PRC, in: International

Rable, M. (1994): Conflict resolution and ethnicity. WesportWestport: Praeger.

Radenkovic, I. (2016): Foreign Direct Investment in Serbia. Beograd: Rosa Luxemburg Stiftung Southeast Europe, Standard 2.

Rahim, M. A. (1983): A measure of styles of handling interpersonal conflict, in: The Academy of Management Journal, 26, 2, 368-76. 
Rahim, M. A. (1986): Referent role and styles of handling interpersonal conflict, in: Journal of Social Psychology, 126, 1, 79-86.

Rahim, M. A. (2002): Toward a theory of managing organizational conflict, in: International Journal of Conflict Management, 13, 3, 206-36.

Ristic, M.R./Selakovic, M./Qureshi, T. M. (2017): Employee motivation strategies and creation of supportive work environment in societies of post-socialist transformation, in: Polish Journal of Management Studies, 15, 2, 205-216.

Schneider, S./Barsoux, J. (1997): Managing Across Cultures. Hertfordshire: Prentice Hall

Schroll-Machl, S. (2013): Doing business with Germans: Their perception, our perception. Gottingen: Vandenhoeck \& Ruprecht.

Shadare, A. O./Chidi, O.C./Owoyemi, O.A. (2011): Gender influences on managerial style and conflict resolution effectiveness in work organizations in south westerns Nigeria, in: International Journal of Business Administration, 2, 1, 54-60.

Shute, R./Charlton, K. (2006): Anger or compromise? Adolescents' conflict resolution strategies in relation to gender and type of peer relationship, in: International Journal of Adolescence and Youth, 13, 55-69.

Studies of Management and Organization, 20, 1, 120-129.

Tannen, D. (1990): You Just Don't Understand: Women and Men in Conversation. New York: William Morrow.

Taylor, D. M./Moghaddam, F. M. (1994): Theories of intergroup relations: International social psychological perspectives. Westport: Praeger Publishers.

The German-Serbian Chamber of Commerce (AHK) (ed.) (2018): Annual survey on the economic environment, Belgrade.

Ting-Toomey, S. (1988): A face-negotiation theory, in Kim, Y. /./Gudykunst, W. (eds): Theories in Intercultural Communication, Newbury Park, CA: Sage, 213-35.

Ting-Toomey, S. (1999): Communicating across Cultures. New York: Guilford Press.

Ting-Toomey, S. (2005): The matrix of face: An updated face-negotiation theory, in Gudykunst, W. B. (ed.): Theorizing about intercultural communication, Thousand Oaks, CA: Sage: 211-234.

Ting-Toomey, S./Gao, G./Trubisky, P./Yang, Z./Soo Kim, H./Lin, S.-L./Nishida, T. (1991): Culture, face, maintenance, and styles of handling interpersonal conflict: A study in five cultures, in: International Journal of Conflict Management, 2,4, 275-296.

Ting-Toomey, S./Yee-Jung, K.K./Shapiro, R.B./Garcia, W./Wright, T.J./Oetzel, J. G. (2000): Ethnic/cultural identity salience and conflict styles in four US ethnic group, in: International Journal of Intercultural Relations, 24,1, 47-81.

Triandis, H.C. (1995): Individualism and collectivism. Boulder: Westview Press.

Trompenaars, F./ Hampden-Turner, C./ Fons, T. (2007): Riding the Waves of Culture: Understanding Diversity in Business 3/E. McGraw-Hill Professional.

Trubisky, P./Ting-Toomey, S./Lin, S. (1991): The influence of individualism-collectivism individualism-collectivism and self-monitoring on conflict styles, in: International Journal of Intercultural Relations, 15, 65-84.

Wang, G., Jing, R. /./Klossek, A. (2007): Antecedents and management of conflict, in: International Journal of Conflict Management, 18, 1, 74-88. 
Wood, V. F./Bell, P.A. (2008): Predicting interpersonal conflict resolution styles from personality characteristics, in: Personality and Individual Differences, 45, 2, 126-131.

Yelsma, P./Brown, C.T. (1985): Gender roles, biological sex and predisposition of conflict management, in: Sex Roles, 12, 731-45.

Zabkar, V./Makovec Brencic, M. (2004): Values, trust, and commitment in business-to-business relationships: A comparison of two former Yugoslav markets, in: International Marketing Review, 21, 2, 202-215. 